\title{
Preliminary Study of Body Temperature Emissivity in Rabbits Selected for Litter Size Residual Variability
}

\author{
Iván Agea *(D), María de la Luz García (D) and María-José Argente \\ Centro de Investigación e Innovación Agroalimentaria y Agroambiental (CIAGRO-UMH), Miguel Hernández \\ University, Ctra. de Beniel km 3.2, 03312 Orihuela, Spain; mariluz.garcia@umh.es (M.d.l.L.G.); \\ mj.argente@umh.es (M.-J.A.) \\ * Correspondence: iagea@umh.es; Tel.: +34-663-958-933
}

Citation: Agea, I.; García, M.d.1.L.; Argente, M.-J. Preliminary Study of Body Temperature Emissivity in Rabbits Selected for Litter Size Residual Variability. Agriculture 2021, 11, 604. https://doi.org/10.3390/ agriculture11070604

Academic Editor:

Agnieszka Ludwiczak

Received: 31 May 2021

Accepted: 25 June 2021

Published: 28 June 2021

Publisher's Note: MDPI stays neutral with regard to jurisdictional claims in published maps and institutional affiliations.

Copyright: (c) 2021 by the authors. Licensee MDPI, Basel, Switzerland. This article is an open access article distributed under the terms and conditions of the Creative Commons Attribution (CC BY) license (https:/ / creativecommons.org/licenses/by/ $4.0 /)$.

\begin{abstract}
A divergent selection for litter size residual variability has been carried out in rabbits during 12 generations. Litter size residual variability was estimated as phenotypic variance of litter size within females after correcting for the year-season and the parity-lactation status effects. Stress causes an increase in core body temperature. Infrared thermography (IRT) has been shown to be a useful technique for identifying changes in body temperature emissivity. The aim of this work is to study the correlated response to selection for litter size residual variability in body temperature emissivity at natural mating. Natural mating can be considered a stressful stimulus for does. Temperature was measured in the eyeball by IRT before mating (basal temperature) and after $5 \mathrm{~min}, 30 \mathrm{~min}$, and $60 \mathrm{~min}$ in does of the lines selected to decrease and to increase litter size residual variability (i.e., the Low and the High lines). Both lines showed similar basal temperature. Eyeball temperature was increased slightly in the Low line from basal state to $5 \mathrm{~min}$ after stressful stimulus (from $35.69^{\circ} \mathrm{C}$ to $36.32{ }^{\circ} \mathrm{C}$ ), and this increase remained up to $60 \mathrm{~min}$ after stress $\left(36.55^{\circ} \mathrm{C}\right)$. The High line showed a higher temperature than the Low line at $30 \mathrm{~min}\left(+0.96^{\circ} \mathrm{C}, p=0.99\right)$. At $60 \mathrm{~min}$, temperature was similar between lines. The evolution of temperature was different between lines: the High line reached the peak of temperature later than the Low line (at $30 \mathrm{~min}$ vs. $5 \mathrm{~min}$ ), and its peak was higher compared to the Low line $\left(36.95{ }^{\circ} \mathrm{C}\right.$ vs. $\left.36.32{ }^{\circ} \mathrm{C}\right)$. In conclusion, the does selected for reducing litter size variability showed a lower increase in temperature after a stressful stimulus, therefore showing lower stress and consequently better welfare.
\end{abstract}

Keywords: fertility; lactation; rabbit; selection; stress; temperature; thermography

\section{Introduction}

Livestock industry and consumer are increasingly concerned on farm animal welfare. Animal welfare is directly related to animal's stress and healthy. Stress has commonly been measured not only by cortisol levels in blood but also as cortisol metabolites in feces, hair, and urine [1]. Neutrophil-lymphocyte ratio has been employed as a stress measurement as well [2], because the duration of stress affects leucocyte populations [3]. However, a major issue for animal welfare is that these techniques involve invasive procedures which may themselves cause a stress response and therefore affect the measurement of interest [4].

Infrared thermography (IRT) is an accepted technique for measuring body heat losses [5]. This technique has been used to find differences in body temperature emissivity in eyes, ears and nose in rabbits stressed due to environmental challenges [6]. IRT technique has the advantage of being fast, non-invasive and requiring minimal handling of the animals [4]. A higher body temperature in rabbits has been related to a higher level of cortisol metabolites in feces and therefore to higher stress [6,7]. The monitoring of the body surface temperature variations in animals can be used to assess the onset of estrus, the inflammatory processes, the adaptability to heat, and the tolerance to stress [8].

A divergent selection experiment for litter size residual variance has been performed successfully in rabbits. The High line and the Low lines diverged around 5\% from the 
original mean per generation [9]. Litter size residual variance has directly related to environmental sensitivity, i.e., with coping of animals to environmental challenges [10]. In this regard, the Low line presented a better behavior against stress and diseases, and in consequence culling rate was lower in the Low line than in the High line [11]. Moreover, the Low line showed better body condition and lower fat mobilization at situations of high-energy demand [12]. Therefore, selection for reducing litter size residual variance could be a useful tool to improve welfare in dams. The aim of this work is to study the correlated response to selection for litter size residual variability in the development of body temperature emissivity.

\section{Materials and Methods}

\subsection{Ethics Statement}

All experimental procedures were approved by the Miguel Hernández University of Elche Research Ethics Committee, according to Council Directives 98/58/EC and 2010/63/EU (reference number 2017/VSC/PEA/00212).

\subsection{Experimental Animals}

A divergent selection experiment was carried out for litter size variability over twelve generations (High and Low line). The selection was based on the phenotypic variation of the litter size within the female, after correcting the litter size for both the year-season and the parity-lactation status. All the animals were bred in individual cages $(37.5 \mathrm{~cm} \times 33 \mathrm{~cm} \times 90 \mathrm{~cm})$ indoor at the farm of the Miguel Hernández University (Spain). The does were mated the first time at 18 weeks of age and later at 10 days after delivery. The non-receptive does were mated again the following week. Fertile natural matings were considered those that ended in parturition. The pregnancy diagnosis was made by abdominal palpation 12 days after natural mating, and the kits were weaned at 28 days of age.

An experiment was performed to analyze the progress in body temperature of does in the first hour after natural mating. Each doe was moved to a male cage for natural mating. After copulation, the doe was returned to her cage. Handling, grouping, and mating are considered stressful stimuli [13-15]. The body temperature emissivity was measured by IRT of the eyeball. All IRTs were performed on the does' cages.

A total of 21 does of the Low line and 22 does of the High line were used to measure the eyeball temperature emissivity before the second natural mating, and at 5, 30, and $60 \mathrm{~min}$ later. The temperature recorded before the second natural mating was considered the basal temperature. The experiment was carried out in two sessions with an environmental temperature of $20^{\circ} \mathrm{C}$ and $24^{\circ} \mathrm{C}$.

Another experiment was performed to study the effect of environment, lactation status and fertility in basal temperature and in range between the basal temperature and $60 \mathrm{~min}$ after natural mating with the same procedures of the first experiment. The temperature emitted by the eyeball was measured in 56 does of the Low line and 37 does of the High line. The experiment was carried out in 11 sessions that were grouped according to the environmental temperature (Table 1).

Table 1. Distribution of thermographic sessions according to environmental temperature.

\begin{tabular}{ccc}
\hline & Environment 1 & Environment 2 \\
\hline Number of sessions & 4 & 7 \\
Number of does & 46 & 47 \\
Mean temperature $\left({ }^{\circ} \mathrm{C}\right)$ & 12.5 & 18.1 \\
Standard deviation $\left({ }^{\circ} \mathrm{C}\right)$ & 0.95 & 1.51 \\
\hline
\end{tabular}

All temperature emissivity images were taken at $0.7 \mathrm{~m}$ of the doe with a ${ }^{\circledR}$ FLIR SC660 thermal imaging camera and processed with ${ }^{\circledR}$ ThermaCAM Researcher Pro 2.10 software 
to obtain the temperature record (Figure 1). Two thermographs of each rabbit were taken at each moment, and the maximum temperature recorded in each pair was averaged.

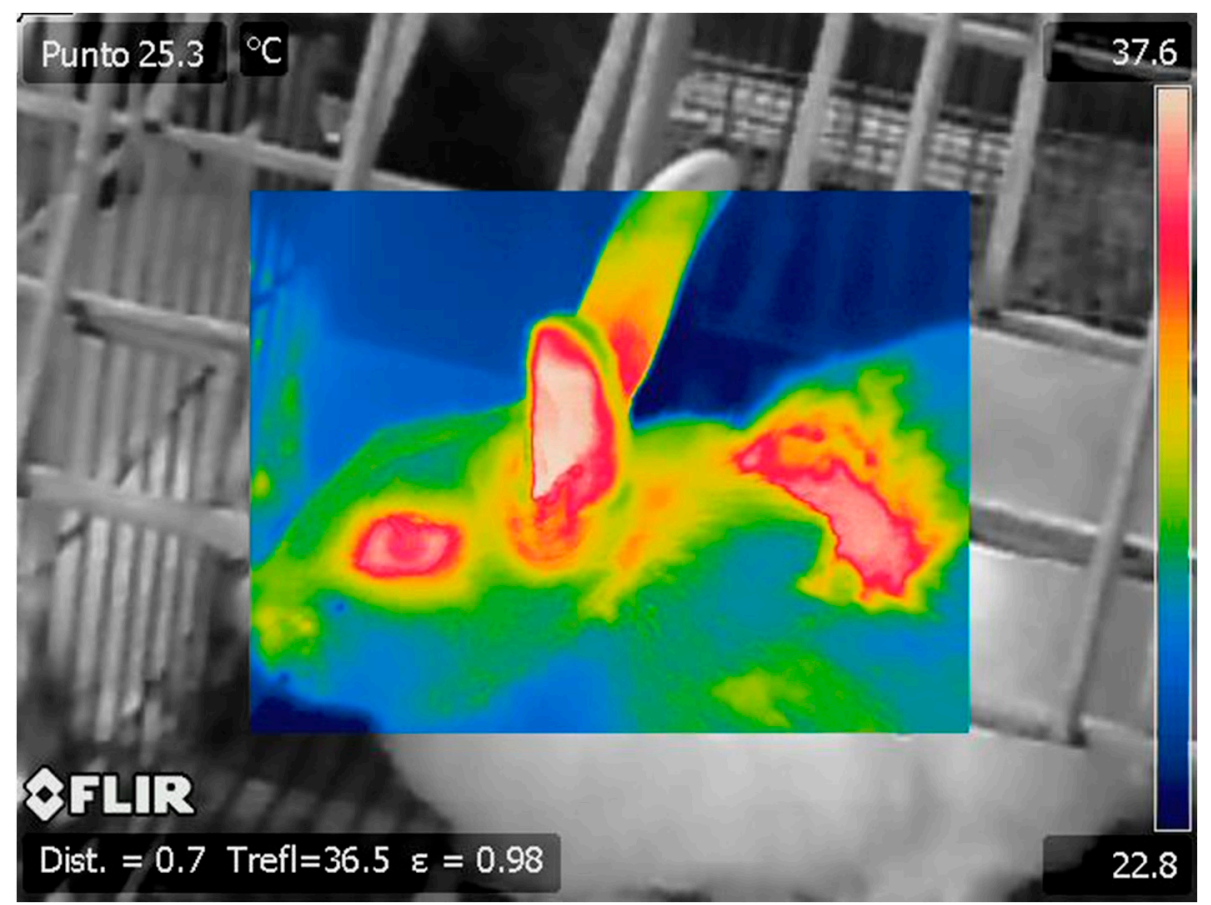

Figure 1. Thermographic image of a rabbit photographed with the ${ }^{\circledR}$ FLIR SC660 thermal imaging camera.

\subsection{Traits}

The following traits were analyzed: temperature just before the second mating (basal temperature), temperature 5, 30, and 60 min after mating, temperature range, and individual weight at mating. Temperature range was defined as the difference between basal temperature and 60 min after mating.

\subsection{Statistical Analysis}

The model for analyzing the progress in temperature in the first hour after stressful stimulus included the effects of environmental temperature (two levels: session 1 with environmental temperature of $20^{\circ} \mathrm{C}$ and session 2 with environmental temperature of $24^{\circ} \mathrm{C}$ ) and line-moment (eight levels; low line before mating, low line at $5 \mathrm{~min}$, low line at $30 \mathrm{~min}$, low line at $60 \mathrm{~min}$, high line before mating, high line at $5 \mathrm{~min}$, high line at $30 \mathrm{~min}$, and high line at $60 \mathrm{~min}$ ), the random effect of female, and female weight as covariate.

The model for analyzing the effect of environment, lactating status, and fertility included the effects of environmental temperature (two levels, see Table 1), lactation status (two levels: lactating and non-lactating does), fertile mating (two levels; fertile and nonfertile), line (two levels; the Low line and the High line), and female weight as covariate.

All analyses were performed using Bayesian methodology [9]. Bounded uniform priors were used for all effects with the exception of the female effect, which was considered normally distributed with mean 0 and variance $\mathrm{I} \sigma_{f}^{2}$, where $\mathrm{I}$ is a unity matrix and $\sigma_{f}^{2}$ is the variance of the female effect. Female and residual effects were considered to be independent. Residuals were a priori normally distributed with mean 0 and variance $\mathrm{I} \sigma_{e}^{2}$. The priors for the variances were also bounded uniform. Features of the marginal posterior distributions for all unknowns were estimated using Gibbs sampling. The Rabbit program developed by the Institute for Animal Science and Technology (Valencia, Spain) was used for all procedures. A chain of 60,000 samples was used, with a burn-in period of 10,000 . Only one out of every 10 samples was saved for inferences. Convergence was 
tested using the $\mathrm{Z}$ criterion of Geweke and Monte Carlo sampling errors were computed using time-series procedures.

\section{Results}

\subsection{Correlated Response to Selection in Temperature Emissivity}

Figure 2 shows that the Low and the High lines displayed similar eyeball temperature at baseline moment. The Low line increased slightly eyeball temperature at $5 \mathrm{~min}$ after stressful stimulus (from $35.69{ }^{\circ} \mathrm{C}$ to $36.32{ }^{\circ} \mathrm{C}$ ), and this increase remained up to $60 \mathrm{~min}$ after stress $\left(36.55^{\circ} \mathrm{C}\right)$. The High line showed higher temperature than the Low line at $30 \mathrm{~min}\left(+0.96{ }^{\circ} \mathrm{C}, p=0.99\right)$. At $60 \mathrm{~min}$, temperature was similar between lines. The evolution of temperature was different between lines, since the High line reached the peak of temperature later than the Low line (at $30 \mathrm{~min}$ vs. $5 \mathrm{~min}$ ), and its peak was higher compared to the Low line $\left(36.95{ }^{\circ} \mathrm{C}\right.$ vs. $\left.36.32{ }^{\circ} \mathrm{C}\right)$.

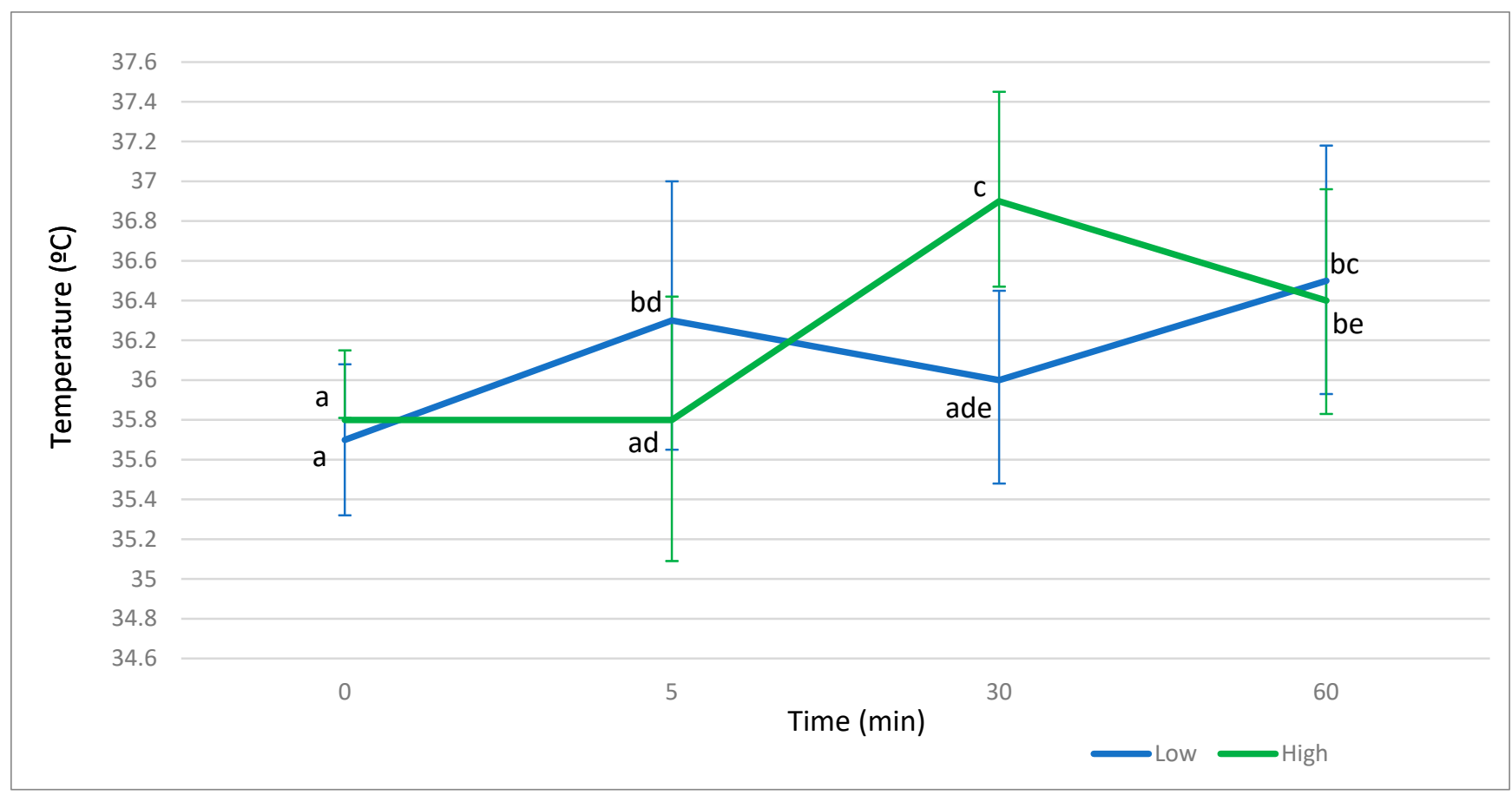

Figure 2. Evolution of eyeball temperature to basal time, $5 \mathrm{~min}, 30 \mathrm{~min}$, and $60 \mathrm{~min}$ after stressful stimulus in the Low and the High line. Different letters mean differences with $p$ greater than 0.90 . Bars indicate highest posterior density region at $95 \%$.

\subsection{Effect of Season and Lactating Status of Does in Eyeball Temperature}

Table 2 shows the features of marginal posterior distributions of the difference between Environment 1 and Environment 2 for basal eyeball temperature and temperature range. Does showed lower basal temperature emissivity in Environment $1\left(-1.09^{\circ} \mathrm{C}, p=1\right)$ than in Environment 2. No evidence of difference in temperature variation was found between environments $(p=0.79)$.

Table 2. Effect of Environments on basal temperature and temperature range between basal and $60 \mathrm{~min}$.

\begin{tabular}{|c|c|c|c|c|c|}
\hline Time $(n=93)$ & Environment 1 & Environment 2 & $D_{\text {Env1-Env2 }}$ & $\mathrm{HPD}_{95 \%}$ & $p$ \\
\hline Basal & 32.19 & 33.28 & -1.09 & $-1.78,-0.39$ & 1 \\
\hline Basal-60 min & 2.01 & 2.32 & -0.31 & $-1.07,0.44$ & 0.79 \\
\hline
\end{tabular}

n: number of data. DEnv1-Env2: differences in eyeball temperature between Environments [1 and 2]. HPD $95 \%$ : highest posterior density region at $95 \%$. $p$ : probability of the difference being $>0$ when $D_{\text {Env1-Env2 }}>0$ or being $<0$ when DEnv1-Env2 $<0$. 
Table 3 shows the features of marginal posterior distributions of the difference between lactating and non-lactating does for basal eyeball temperature and between basal eyeball temperature and $60 \mathrm{~min}$ after the stressful stimulus of mating. Non-lactating does had higher basal temperature than lactating ones $\left(+0.60^{\circ} \mathrm{C}, p=0.97\right)$. It should be noted that non-lactating does showed lower temperature variation between basal eyeball temperature and $60 \mathrm{~min}$ after stressful stimulus than lactating does $\left(-0.55{ }^{\circ} \mathrm{C}, p=0.92\right)$.

Table 3. Effect of lactation on basal temperature and temperature range between basal and $60 \mathrm{~min}$.

\begin{tabular}{cccccc}
\hline Time $(\boldsymbol{n}=\mathbf{9 3})$ & Non-Lactating $\left({ }^{\circ} \mathbf{C}\right)$ & Lactating $\left({ }^{\circ} \mathbf{C}\right)$ & $\mathbf{D}_{\text {nl-1 }}$ & HPD $_{\mathbf{9 5} \%}$ & $p$ \\
\hline Basal & 33.21 & 32.61 & 0.60 & $-0.01,1.27$ & 0.97 \\
Basal-60 min & 1.82 & 2.37 & -0.55 & $-1.30,0.25$ & 0.92 \\
\hline
\end{tabular}

$\mathrm{n}$ : number of data. $\mathrm{D}_{\mathrm{nl}-1}$ : differences in eyeball temperature between non-lactating and lactating does. $\mathrm{HPD}_{95 \%}$ highest posterior density region at $95 \%$. $p$ : probability of the difference being $>0$ when $D_{n l-1}>0$ or being $<0$ when $\mathrm{D}_{\mathrm{nl}-1}<0$.

Not enough evidence of differences between fertile and non-fertile natural matings in basal eyeball temperature or temperature variation was found (Table 4).

Table 4. Effect of fertility on basal temperature and temperature range between basal and $60 \mathrm{~min}$.

\begin{tabular}{cccccc}
\hline Temperature $(\boldsymbol{n}=\mathbf{9 3})$ & Fertile $\left({ }^{\circ} \mathbf{C}\right)$ & Non-Fertile $\left({ }^{\circ} \mathbf{C}\right)$ & D $_{\text {f-nf }}$ & HPD $_{\mathbf{9 5 \%}}$ & $p$ \\
\hline Basal & 33.99 & 32.85 & 0.12 & $-0.49,0.78$ & 0.64 \\
Basal-60 min & 1.91 & 2.28 & -0.37 & $-1.12,0.39$ & 0.83 \\
\hline
\end{tabular}

n: number of data. $\mathrm{D}_{\mathrm{f} \text {-nf: }}$ differences in eyeball temperature between fertile and non-fertile does. $\mathrm{HPD}_{95 \%}$ : highest posterior density region at $95 \%$. $p$ : probability of the difference being $>0$ when $D_{\mathrm{f}-\mathrm{nf}}>0$ or being $<0$ when $\mathrm{D}_{\mathrm{f}-\mathrm{nf}}<0$.

\section{Discussion}

\subsection{Correlated Response to Selection in Temperature Emissivity}

Different approaches have been developed to improve the ability of animals to cope with environmental perturbations without decreasing their production. Litter size uniformity is directly related to environmental sensitivity. Therefore, selection for litter size residual variance has been shown to be a suitable methodology for obtaining more resilient animals. Beloumi [10] and Argente [11] found that the Low line had a major immunity, a better behavior of inflammatory markers, and a superior reaction against infections, which would be related to a better response of this line to stressful conditions. In a previous study, García [12] found that the Low line made more efficient use of energy reserves than the High line in stages of high demand such as delivery and lactation. This would suggest a better response to stress from the Low line with respect to the High line. In this study, the lines showed a different pattern in the evolution of eyeball temperature after a stressful stimulus. The temperature increased by $3.2 \%$ in the High line, while the increment was almost half in the low line (1.8\%). A higher temperature emissivity is related to a greater effect of stress [6,7]). Thus, our study would provide new evidence of the lower stress sensitivity of the Low line.

As far as we know, this is the first time that the evolution of eyeball temperature after a stressful stimulus has been studied in rabbits. Both lines had a higher eye temperature 60 min after mating than at basal time. Maintaining a high temperature after a stressful stimulus depends on the species. Thus, in sport horses, it has been shown that the temperature emissivity measured in the eye is higher from $5 \mathrm{~min}$ after a competition and even at $3 \mathrm{~h}$ than in its basal state $[16,17]$. In rats, it has been seen that the eye temperature returned to basal level 14 min after the stressful stimulus [18].

\subsection{Effect of Season and Lactating Status of Does in Eyeball Temperature}

The environment temperature is very important for rabbit health because rabbits cannot effectively sweat, and panting is not efficient for cooling [19]. Higher basal eye 
temperature emissivity in Environment 2 (average temperature of $18.1^{\circ} \mathrm{C}$ ) than Environment 1 (average temperature of $12.1^{\circ} \mathrm{C}$ ) was found. Does reacted with higher emissivity of body temperature to keep their homeostasis against the environment with high temperature $[6,7,20]$.

Lactation is considered a stressful period to does. Our results showed that basal eyeball temperature and the increment in temperature from mating to $60 \mathrm{~min}$ later were greater in lactating does than in non-lactating ones. This agrees with higher cortisol levels in lactating does than non-lactating does reported by Argente et al. [21].

Similar basal temperature and temperature range was found in fertile and non-fertile mating. Ovulation in rabbit does is inducted by coitum, and ova are released between 10 and $12 \mathrm{~h}$ after mating [22]. Therefore, our findings show that basal temperature and temperature variations at $10-12 \mathrm{~h}$ before ovulation would have no effect in the fertilization of ova.

\section{Conclusions}

Selection for litter size residual variance showed a correlated response in does' body temperature. The does selected for reducing litter size variability showed a lower increase in temperature after a stressful stimulus, which would suggest a better welfare of these females. This study should be considered preliminary and it will be necessary to conduct additional studies to confirm these results.

Author Contributions: Conceptualization, I.A.; methodology, I.A.; formal analysis, I.A., M.d.l.L.G., and M.-J.A.; data curation, I.A.; writing-original draft preparation, I.A.; writing-review and editing, I.A.; supervision, M.d.l.L.G. and M.-J.A.; and, funding acquisition, M.-J.A. All authors have read and agreed to the published version of the manuscript.

Funding: This research was funded by Ministerio de Ciencia e Innovación (MCI)-Agencia Estatal de Investigación (AEI) and el Fondo Europeo de Desarrollo Regional (FEDER), grant number AGL201786083-C2-2-P.

Institutional Review Board Statement: The study was conducted according to the guidelines of Council Directives 98/58/EC and 2010/63/EU, and approved by the Miguel Hernández University of Elche Research Ethics Committee (protocol code 2017/VSC/PEA/00212).

Informed Consent Statement: Not applicable.

Data Availability Statement: Data are available upon request to the corresponding author.

Acknowledgments: We acknowledge technical support by J.R. Díaz from Miguel Hernández University of Elche. We acknowledge A. Blasco for his comments.

Conflicts of Interest: The authors declare no conflict of interest.

\section{References}

1. Möstl, E.; Palme, R. Hormones as indicators of stress. Domest. Anim. Endocrinol. 2002, 23, 67-74. [CrossRef]

2. Widowski, T.M.; Curtis, S.E.; Graves, C.N. THE NEUTROPHIL:LYMPHOCYTE RATIO IN PIGS FED CORTISOL. Can. J. Anim. Sci. 1989, 69, 501-504. [CrossRef]

3. Urbanová, M.; Kramářová, E.; Chloupek, J.; Najmanová, M. Evaluation of stress in laboratory rabbits used for teaching purposes. Acta Vet. Brno 2019, 88, 249-255. [CrossRef]

4. Stewart, M.; Webster, J.R.; Schaefer, A.L.; Cook, N.J.; Scott, S.L. Infrared thermography as a non-invasive tool to study animal welfare. Anim. Welf. 2005, 14, 319-325.

5. Ricci, G.D.; Da Silva-Miranda, K.O.; Titto, C.G. Infrared thermography as a non-invasive method for the evaluation of heat stress in pigs kept in pens free of cages in the maternity. Comput. Electron. Agric. 2019, 157, 403-409. [CrossRef]

6. de Lima, V.; Piles, M.; Rafel, O.; López-Béjar, M.; Ramón, J.; Velarde, A.; Dalmau, A. Use of infrared thermography to assess the influence of high environmental temperature on rabbits. Res. Vet. Sci. 2013, 95, 802-810. [CrossRef]

7. Marai, I.; Ayyat, M.; El-Monem, U.A. Growth Performance and Reproductive Traits at First Parity of New Zealand White Female Rabbits as Affected by Heat Stress and Its Alleviation under Egyptian Conditions. Trop. Anim. Health Prod. 2001, 33, 451-462. [CrossRef] [PubMed]

8. McManus, C.; Tanure, C.B.; Peripolli, V.; Seixas, L.; Fischer, V.; Gabbi, A.M.; Menegassi, S.R.O.; Stumpf, M.T.; Kolling, G.J.; Dias, E.; et al. Infrared thermography in animal production: An overview. Comput. Electron. Agric. 2016, 123, 10-16. [CrossRef] 
9. Blasco, A. Bayesian Data Analysis for Animal Scientists; Springer: Berlin/Heidelberg, Germany, 2018.

10. Beloumi, D.; Blasco, A.; Muelas, R.; Santacreu, M.A.; García, M.D.L.L.; Argente, M.-J. Inflammatory Correlated Response in Two Lines of Rabbit Selected Divergently for Litter Size Environmental Variability. Animals 2020, 10, 1540. [CrossRef] [PubMed]

11. Argente, M.J.; García, M.L.; Zbyňovská, K.; Petruška, P.; Capcarova, M.; Blasco, A. Correlated response to selection for litter size environmental variability in rabbits' resilience. Animal 2019, 13, 2348-2355. [CrossRef]

12. García, M.L.; Blasco, A.; Argente, M.J. Correlated response in body condition and energy mobilisation in rabbits selected for litter size variability. Animal 2019, 13, 784-789. [CrossRef]

13. Rushen, J.; A Taylor, A.; de Passillé, A.M. Domestic animals' fear of humans and its effect on their welfare. Appl. Anim. Behav. Sci. 1999, 65, 285-303. [CrossRef]

14. Gerencsér, Z.; Matics, Z.; Szabó, R.T.; Kustos, K.; Mikó, A.; Nagy, I.; Odermatt, M.; Atkári, T.; Szendrő, Z. Aggressiveness, Mating Behaviour and Lifespan of Group Housed Rabbit Does. Animals 2019, 9, 708. [CrossRef] [PubMed]

15. Bakker, J.; Baum, M.J. Neuroendocrine Regulation of GnRH Release in Induced Ovulators. Front. Neuroendocr. 2000, 21, $220-262$. [CrossRef] [PubMed]

16. Valera, M.; Bartolomé, E.; Sánchez, M.J.; Molina, A.; Cook, N.; Schaefer, A. Changes in Eye Temperature and Stress Assessment in Horses During Show Jumping Competitions. J. Equine Vet. Sci. 2012, 32, 827-830. [CrossRef]

17. Bartolomé, E.; Sánchez, M.J.; Molina, A.; Schaefer, A.L.; Cervantes, I.; Valera, M. Using eye temperature and heart rate for stress assessment in young horses competing in jumping competitions and its possible influence on sport performance. Animal 2013, 7, 2044-2053. [CrossRef]

18. Vianna, D.M.L.; Carrive, P. Changes in cutaneous and body temperature during and after conditioned fear to context in the rat. Eur. J. Neurosci. 2005, 21, 2505-2512. [CrossRef]

19. Marai, I.; Habeeb, A.; Gad, A. Rabbits' productive, reproductive and physiological performance traits as affected by heat stress: A review. Livest. Prod. Sci. 2002, 78, 71-90. [CrossRef]

20. Jaén-Téllez, J.A.; Sánchez-Guerrero, M.J.; López-Campos, J.I.; Valera, M.; González-Redondo, P. Acute stress assessment using infrared thermography in fattening rabbits reacting to handling under winter and summer conditions. Span. J. Agric. Res. 2020, 18, e0502. [CrossRef]

21. Argente, M.-J.; García, M.D.L.L.; Birlanga, V.; Muelas, R. Relationship between cortisol and acute phase protein concentrations in female rabbits. Vet. J. 2014, 202, 172-175. [CrossRef]

22. Bosco, A.D.; Rebollar, P.; Boiti, C.; Zerani, M.; Castellini, C. Ovulation induction in rabbit does: Current knowledge and perspectives. Anim. Reprod. Sci. 2011, 129, 106-117. [CrossRef] [PubMed] 